\title{
Improving Student Learning Outcomes in Science Subjects Using Explicit Instruction Learning Models in Elementary School of Ulu Brayun Langkat Regency
}

\author{
Nurmayani $^{1 *}$, Nurul Atika Arsilda ${ }^{2}$ \\ 1,2)Universitas Negeri Medan, Indonesia \\ *nurmayani111161@gmail.com
}

\begin{abstract}
The purpose of this study is to analyze the achievements of student learning outcomes in subjects natural light and its properties by using the Explicit Instruction learning model in Elementary School 050669 Ulu Brayun Langkat Regency. This research is "Classroom Action Research" consisted of 2 cycles. The subjects were grade $\mathrm{V}$ students with a total of 28 students, while the object of this study was the use the model of of Explicit Instruction learning to improve learning outcomes of student. The instrument of data collection are tests and observation sheets. Based on the results showed from the number of 28 students that in the first cycle the average value was 66.25 , while in the second cycle the average value was 80.35 . Student learning outcomes in each cycle also increased. In the first cycle of 17 students who completed the KKM score with a percentage of $60.71 \%$, while 11 students did not complete with a percentage of $39.28 \%$. In cycle II there was also an increase of 24 students who completed the KKM score with a percentage of $85.71 \%$, while only 4 students did not complete with a percentage of $14.28 \%$. For the results of the percentage of teachers in each cycle also increased in the first cycle the value of the percentage obtained by teachers $70.83 \%$, in the second cycle the results obtained were $92.71 \%$. The research findings state the Explicit Instruction learning model is proven to be able to improve student achievement in natural science subjects.
\end{abstract}

Keywords: Learning Outcomes, Explicit Instruction

\section{Introduction}

Education has important role to develop the personality and intellectual development of children, as well as the study of natural science. Natural science lessons are taught from the elementary school level, where natural science is learning based on principles, a process which can foster students' scientific attitudes towards the concepts of natural science [1]. One of the goals of learning natural science is to develop knowledge and understanding of natural science concepts that are useful and can be applied in everyday life [2]. But the fact that there is a learning goal of natural science in some schools at the elementary school level has not been reached optimally.

One that influences the level of success in learning natural science is the presence of student learning outcomes in carrying out natural science learning. According to Simanjuntak [1] learning outcomes are the mastery of students in cognitive, affective and psychomotor aspects by linking the initial mastery they have received. Student learning outcomes are strongly influenced by the teacher's role in choosing theory and composing learning strategies 
that will be applied according to all subjects, the teacher must create learning activities that are able to build students' ability to understand the subject. In addition, teachers can help students who are developing to learn something that is not yet known, forming competencies, understanding the standard material being studied and realizing optimal life goals of students [3]. The task of the teacher as a teacher and educator is not only to convey information for the achievement of learning objectives, but also to create learning experiences for students.

But the reality in the field there is a low student learning outcomes when learning can be seen from students who do not master and understand the theory and relate it in daily life, this is caused by teachers who do not design learning methods for students where teaching and learning activities are centered on the teacher ( teacher centered), the teacher only explains the subject matter continuously without any feedback from students, so students only receive explanations from the teacher.

The learning method applied by the teacher is less varied. The teacher only uses the lecture method when delivering the subject matter. This causes teachers to be less creative in teaching and learning activities and teachers do not use learning strategies that can encourage students to actively think so that students are less able to develop their ability to think critically, creatively, innovatively, as a result students are less enthusiastic in learning, and students lack direct experience in study [4].

Many students have difficulty in the learning process of natural science, where many theories must be memorized and understood by students, and in general students cannot answer every question posed by the teacher, both before the learning activities take place and after the completion of the learning process, this causes the lack of student activity in teaching and learning activities $[5,6]$. So it has an impact on the low student learning outcomes and is evident in the evaluation obtained by students not in accordance with the standard of mastery learning which is still below the expected average KKM (minimum completeness criteria) which is 70 .

To overcome these conditions the researchers designed the learning process using the Explicit Instruction model. The Explicit Instruction Model is known as direct teaching or clear instructions. Explicit Instruction Strategy is one of the teaching approaches specifically designed to support student learning processes [7] This strategy is related to declarative knowledge and procedural knowledge that is structured and can be taught in a pattern of gradual, step-by-step activities that requires students to be active in each learning activity. In the implementation of the Explicit Instruction (EI) model, it can take the form of lectures, demonstrations, training or practice and group work.

Based on data analysis of the study showed from the number of 28 students in grade $\mathrm{V}$ 050669 elementary school Ulu Brayun that in the first cycle the average value was 66.25 , while in the second cycle was 80.35 . Student learning outcomes in each cycle also increased. In the first cycle of 17 students who completed the KKM score with a percentage of $60.71 \%$, while 11 students did not complete with a percentage of $39.28 \%$. In cycle II there was also an increase of 24 students who completed the KKM score with a percentage of $85.71 \%$, while only 4 students did not complete with a percentage of $14.28 \%$. For the results of the percentage of teachers in each cycle also increased in the first cycle the value of the percentage obtained by teachers $70.83 \%$, in the second cycle the results obtained were $92.71 \%$.

The Explicit Instruction learning model chosen is expected to make students more active and give students a high learning experience. In addition, students will get guidance from the teacher gradually, seeing that students have not received prior training, so that each student understands the learning provided and gets the maximum learning results. 


\section{.2 Research Method}

This study is an Action Research Classroom, carried out using cycles which are a solution by making improvements, improvements, and changes towards improvement so that learning objectives can be achieved [5]. The subjects were fifth grade students of SDN 050669 Ulu Brayun, totaling 28 students, 15 male and 13 female students. The object of this research is the learning outcomes of students in the subject matter of light science and its properties and the Explicit Instruction learning model $[8,9]$. The research design uses classroom action research with the model proposed by Arikunto [2] conducted using a cycle, as follows:

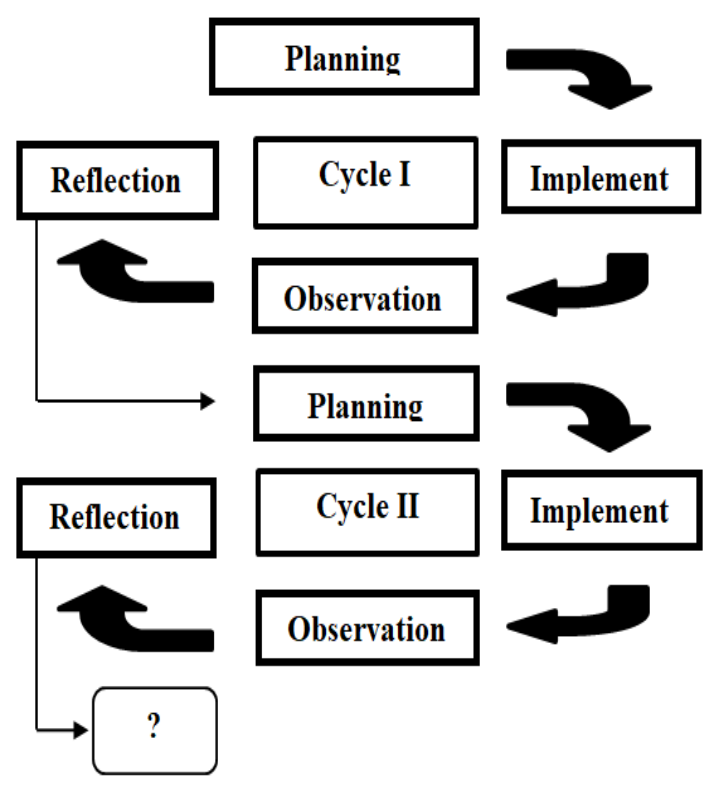

Figure 1. Picture of Class Action Implementation Scheme

Data collection techniques used to determine student learning outcomes using Explicit Instruction learning are tests and observations. Students' ability to complete the test results of learning outcomes is assessed using a scale of $0-100$ in the following way [3]:

$$
\text { Value }=\frac{\text { Scores obtained by students }}{\text { Maximum number of scores }} \times 100
$$

\section{Results and Discussion}

Based on the classical results of the study the increase in the average value of student learning outcomes from cycle I (meetings I and II) and cycle II (meetings I and II) like this table below: 
Table 1. Scoring in the Average Value of Learning Outcomes

\begin{tabular}{ccc}
\hline No. & Learning Outcomes Test & Average value \\
\hline 1. & Pre test & 51,07 \\
2. & Cycle Test I & 66,25 \\
3. & Cycle Test II & 80,35 \\
\hline
\end{tabular}

Based on $t_{\text {tabel }} 1$, the average value of pre-test is 51.07 , the average value of student learning outcomes on the first cycle test is 66.25 and the average value of student learning outcomes on the second cycle test is 8035 . After having done the pre-test, out of 28 students only 7 students were complete $(25 \%)$ and 21 students were incomplete $(75 \%)$, in the post test cycle I increased to 17 students who completed (60.71\%) and 11 students were incomplete (39.28\%), and post test cycle II student learning outcomes greatly increased to 24 students who completed (85.71\%) and only 4 students who did not complete (14.28).

From the recapitulation results above, the acquisition of learning outcomes in natural science subjects from pre-test, cycle I and cycle II increases and is complete. In more detail, the comparative data of pre-test, cycle I and cycle II learning outcomes can be illustrated in the diagram as follows:

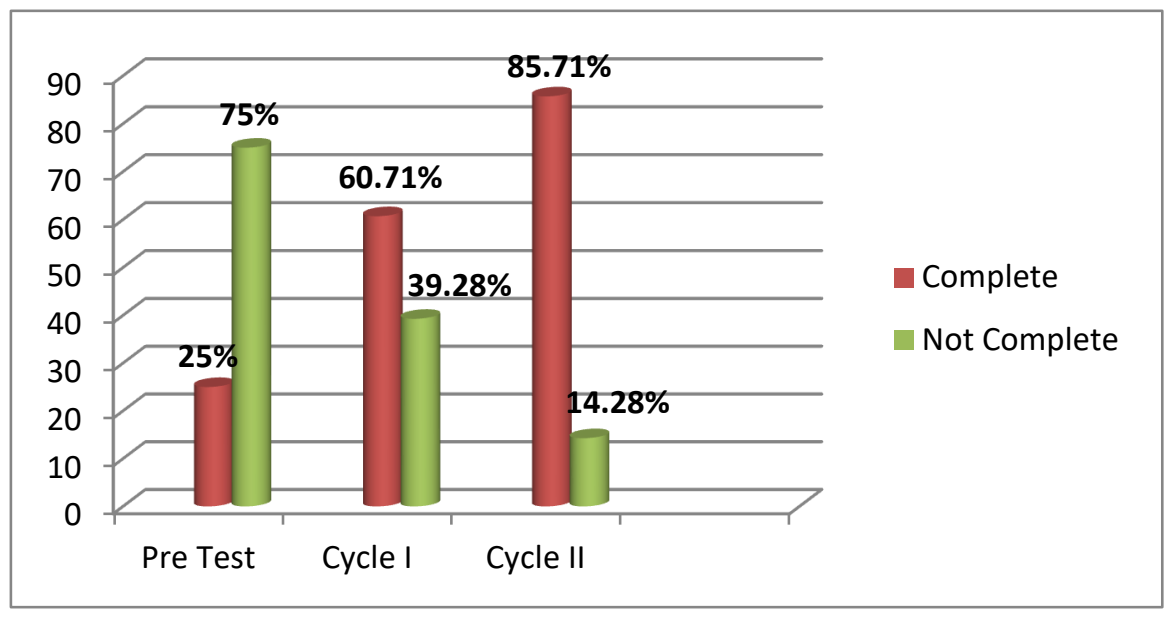

Figue 2. Comparison Diagram of Pre Test Results, and Cycle

Based on the diagram above it can be seen clearly the comparison of students completeness before being treated with a percentage of $25 \%$ to $60.71 \%$, while the results of teacher observation with a percentage of $70.83 \%$, and the results of student observation with a percentage of $71.87 \%$ are quite good, after given treatment actions in cycle I. And increasing again after being given treatment in the second cycle with a percentage of completeness $85.71 \%$ and the results of teacher observation with a percentage of $91.71 \%$, and the results of observation of students with a percentage of $87.5 \%$ classified as very good. Students who have not improved their learning outcomes are given special guidance on a regular basis.

Thus it can be concluded that the level of completeness of student learning outcomes significantly increases with application of the EIL model in the subject of natural science of 
light material and its properties in class V SDN 050669 Ulu Brayun is the same as the results of research by Megawati with title "The Implementation of Explicit Instruction Learning Model to Improve Student Learning Outcomes in Science Subjects in Class V SDN Ginunggung Tolitoli", this study reflects that the application of Expliicit Instruction learning models can improve student learning outcomes. The results of this study are in line with previous studies such as Simanjuntak, Eva Betty [1], Chrisnaji Banindra Yudha [2019].

\section{Conclusion}

Based on the results of research and discussion that has been conducted on increasing student learning outcomes in light material and its properties by using the Explicit Instruction learning model in class V SDN 050669 Ulu Brayun, the researchers make the following conclusions:

a. Learning by using the Explicit Instruction learning model can improve student learning outcomes in light material and its properties and this can be seen from the increase in value acquisition in each cycle.

b. In the pre-test, only 7 students completed the KKM score with a percentage of $25 \%$, while 21 students did not complete the percentage of $75 \%$. The average pre test score of students is 51.07 .

c. After the first cycle, using the Explicit Instruction learning model, an increase of 17 students who completed the KKM score with a percentage of $60.71 \%$, while 11 students did not complete with a percentage of $39.28 \%$. The average value of the post test in the first cycle is 66.25 and the results of teacher observation with a percentage of $70.83 \%$, and the results of student observations with a percentage of $71.87 \%$ are quite good.

d. In cycle II there was also an increase of 24 students who completed the KKM score with a percentage of $85.71 \%$, while only 4 students did not complete with a percentage of $14.28 \%$. The average value of the post test cycle II is 80.35 and the observation results of teachers with a percentage of $91.71 \%$, and the results of student observations with a percentage of $87.5 \%$ are classified as very good.

\section{References}

[1] Simanjuntak, Eva Betty, (2015), Pengaruh Strategi Pembelajaran dan Motivasi Berprestasi Terhadap Hasil Belajar Penelitian Tindakan Kelas (PTK) Mahasiswa Pgsd Fip Unimed. School Education Journal Pgsd Fip Unimed, 3 (1), pp.105-106.

[2] Arikunto, Suharsimi. (2017), Penelitian Tindakan Kelas. Jakarta: Bumi Aksara.

[3] Istarani, (2015), Model Pembelajaran Inovatif. Medan: Media Persada.

[4] Mujiono, (2013), Belajar dan Pembelajaran. Jakarta: Rineka Cipta.

[5] Purwanto, (2017), Evaluasi Hasil Belajar. Yogyakarta: Pustaka Belajar.

[6] Miftahul Huda, (2017), Model-Model Pengajaran dan Pembelajaran. Yogyakarta: Pustaka Pelajar.

[7] Agus Suprijono, (2010), Cooperative Learning. Yogyakarta: Pustaka Belajar. 
[8] Susanto, Ahmad, (2016), Teori Belajar \& Pembelajaran di Sekolah Dasar. Jakarta: Kencana.

[9] Trianto, (2014), Mendesain Model Pembelajaran Inovatif, Progresif, dan Kontekstual. Jakarta Prenadamedia Grup.

[10] Chrisnaji Banindra Yudha, (2019), Penerapan Project Based Learning dalam Mata Kuliah Penelitian Tindakan Kelas. Dwi Cebdikiw, Jurnal Riset Pedagogik, 3(1), pp.30-42. 